\title{
VITAMIN D3 IN ALVEOLAR BONE AUGMENTATION PERFORMED SIMULTANEOUSLY WITH DENTAL IMPLANT PLACEMENT. A CONTROLLED CLINICAL AND RADIOGRAPHIC STUDY
}

\author{
Ahmed Elsayed Hamed Amr*
}

\begin{abstract}
Aim of the study: The aim of this study was to evaluate the effect of vitamin $\mathrm{D}_{3}$ when mixed with xenogenic bone grafts in alveolar ridge augmentation performed simultaneously with implant placement for the management of bony dehiscence defects around dental implant. This included evaluation of the alveolar ridge buccolingual dimensional changes (primary objective) and evaluation of the implant stability changes (secondary objective).
\end{abstract}

Subjects and methods: 14 patients suffering from missing upper anterior tooth and seeking dental implant were included in the study. All the patients showed a residual alveolar ridge with slight bone resorption buccolingually which allowed implant insertion with sufficient stability but with slight bony dehiscence that necessitated simultaneous alveolar bone augmentation with the implant insertion. Group 1 (Test group, 7 patients , received dental implant and alveolar ridge augmentation using customized titanium mesh and xenografts mixed with vitamin D) while Group 2 (Control group, 7 patients, received dental implant and alveolar ridge augmentation using customized titanium mesh and xenografts without vitamin D). Buccolingual (BL) alveolar ridge width changes were evaluated during the study using the cone beam computed tomography (CBCT) while the implant stability changes were evaluated using Osstell Mentor throughout the study.

Results: In both groups, a higher mean buccolingual (BL) alveolar ridge width was recorded 4 months after augmentation. The difference between initial and follow up value was statistically significant. Regarding the percent change in BL width, a higher mean percent increase was recorded in group1, with a statistically significant difference between groups. In both groups, a higher mean value of implant stability (ISQ) was recorded 4 months after augmentation. The difference between initial and follow up value was statistically significant. Regarding the percent change in ISQ, a higher mean percent increase was recorded in group1, with a statistically significant difference between groups.

Conclusion: Vitamin D enhanced the bone formation when mixed with xenografts in alveolar ridge augmentation surgeries. Moreover, it played a role in improving implant stability .

\footnotetext{
* Lecturer of Oral Medicine and Periodontology, Faculty of Dentistry, Ain Shams University
} 


\section{INTRODUCTION}

Nowadays the use of dental implants for the management of partial and complete edentulism yields predictable and successful results with esthetically and functionally accepted prosthesis (Lekholm et al 1999; Weber et al 2000; Leonhardt et al 2002). Unfortunately, partial or complete edentulism is usually associated with quantitative changes in the alveolar ridge related to the loss of teeth and this interfere with the concept of prosthetically-driven dental implants (Schropp et al 2003; Araujo et al 2005). Tooth extraction is usually followed by alveolar ridge resorption especially on the buccal aspect which ends up with unfavorable changes in alveolar ridge size and shape (Araujo \& Lindhe 2005). Several techniques and materials have been proposed to manage alveolar ridge deficiency and reconstruct the alveolar bone ( Chiapasco et al 2006; Donos et al 2008; Rocchietta et al 2008).

According to some authors, alveolar ridge augmentation for treatment of alveolar ridge deficiency can be performed as a separate initial surgery before the second surgery for implant placement (staged approach) (Bell et al 2002; Jemt \& Lekholm 2003; Lizuka et al 2004). They stated that the "staged approach" allows implant placement in vascularized bone with better implant stability, decreased risks of wound dehiscence and decreased incidence of graft infection when compared to the "combined approach". Lundgren et al 1997; Rasmusson et al 1999; Clementini et al 2013 suggested the "combined approach"; where both the implant placement and bone augmentation were performed simultaneously during the same single surgery and they reported that this approach saves treatment time and cost (Mc Grath et al 1996; Vermeeren et al 1996; Van der Meij et al 2005). Moreover, any grafted bone undergoes resorption by time after grafting (Vermeeren et al 1996; Van der Meij et al 2005) but the dimensions of the grafted bone around dental implants in function (combined approach) could be preserved (Kearns et al 1997; Verhoeven et al 2000).

Usually the available alveolar ridge quality and quantity and the ability to achieve primary stability should be the guide to whether use the staged or combined approaches (Chiapasco et al 2006).

Benic and Hammerle 2014 developed a classification for alveolar bone defects to facilitate choosing the suitable procedure and ideal time for alveolar bone augmentation. Class 1; intra-alveolar defect between the implant surface and intact bone walls, Class 2; peri-implant dehiscence where the volume stability of the area to be augmented is provided by the adjacent bony walls, Class 3; periimplant dehiscence where the volume stability of the area to be augmented is not provided by the adjacent bony walls, Class 4; horizontal alveolar ridge defect requiring staged approach for bone augmentation before implant placement, Class 5; vertical alveolar ridge defect requiring staged approach for bone augmentation before implant placement. Class 2 and class 3 bony defects can be augmented simultaneously with the implant placement. In class 2 cases, resorbable barrier membrane and particulate bone graft can be used, while in class 3 cases titanium reinforced barrier membrane with particulate bone graft should be used (Benic and Hammerle 2014).

Xenogenic bone grafts have been widely used in different alveolar ridge augmentation surgeries with highly successful outcomes (Barone et al 2008; Di Stefano et al 2009; Ohayon 2011). Particulate bone graft alone lacks structural integrity. Thus, in bone augmentation around dental implants, it requires a containment system to allow bone graft stabilization and space maintenance (Buser et al 1996; Donos et al 2002). The most commonly used containment systems is the barrier membranes and titanium meshes (Boyne et al 1985; ; Buser et al 1996; Boyne 1997; Schopper et al 2001; Artzi et al 2003). 
Previous studies documented that the use of adjunctive agents (e.g growth factors, hormones and vitamins) in addition to the bone graft used, can enhance the graft properties and lead to successful regenerative results improving implant to bone contact (Qi et al 2004; Lima et al 2013; Xu et al 2015). Active vitamin D3 plays a significant role in homeostasis of bone minerals and can act as a biologically active protein enhancing osteogenesis (Li et al 1998; Lips 2006; Stoffels et al 2006). Vitamin D (Vit D) plays an important role in stimulating calcium absorption in the intestine, regulating activity of the osteoblasts / osteoclasts and bone mineralization (Kraichely \& Mac Donald 1998; Misof et al 2003; Rapuri et al 2007, StArnaud 2008; Kumar et al 2011).

Vit D can be obtained in diet or synthesized naturally in the skin when exposed to sunlight (Lips 2006; Holick 2007) . 7-dehydrocholesterol in the skin absorbs the sunlight and forms previtamin D3 which is quickly changed into vitamin D3. Vitamin D3 is then hydroxylated in the liver then the kidney to form the active form of vitamin D (1,25- dihydroxy vitamin D) (Mac Laughlin et al 1982; DeLuca 2004; Holick 2005a). Previous literature showed that bone and gingival tissues has the enzymes capable of synthesizing the active form of Vit D (Lehmann \& Meurer 2003; Bikle 2004; Hewison et al 2007).

Many studies have documented the positive effect of Vit D supplementation in promoting healing of bone fractures and in increasing callus strength (Brumbaugh et al 1982; Dekel et al 1983; Omeroglu et al 1997; Delgado-Martinez et al 1998). Moreover, other studies proved that increased bone density and reduced fracture rates can be achieved by Vit D and calcium intake (Gallagher \& Goldgar 1990; Chapuy et al 1992; DawsonHughes et al 1997). Previous literature proved that vitamin D receptors are available in most body cells which suggest the wide diverse effects vitamin D can induce on different cells (Landfield et al 1991; Garcion et al 1997; Becker et al 2005).

In vitro studies proved that Vitamin D3 can affect osteoblasts regulation of several genes through interaction with vitamin $\mathrm{D}$ receptors (VDR) on osteoblasts which in turn affect the mineralization and maturation of bone (Gallagher \& Goldgar 1990; Van Leeuwen et al 2001; Miyahara et al 2002). Other animal studies proved that vitamin $\mathrm{D}$ when incorporated with bone grafts can play a significant role in enhancing bone regeneration. (Gogolewski et al 2006; Hong et al 2012)

Moreover in 2013, a study was performed on implants coated with vitamin D3 precursor and showed that this surface treatment may have a positive effect on osteoblasts differentiation and proliferation (Satue et al 2013). Thus, it was tempting to evaluate the effect of vitamin D3 when mixed with bone grafts in alveolar bone regenerative procedures managing bony defects around dental implants.

\section{AIM OF THE STUDY}

The aim of the study was to evaluate the effect of vitamin $\mathrm{D}_{3}$ when mixed with xenografts in alveolar ridge augmentation performed simultaneously with implant placement treating implant dehiscence defects. This will be performed by evaluating the alveolar ridge buccolingual dimensional changes (primary objective) and evaluating the implant stability changes by time (secondary objective).

\section{SUBJECTS AND METHODS}

The study population consisted of 14 patients with age range $28-40$ years. All the patients were selected from the oral diagnosis clinic, faculty of dentistry, Ain Shams University.

Inclusion criteria: All the patients showed missing single maxillary anterior tooth with a residual alveolar ridge showing slight bone resorption buccolingually but enough bone height. 
The buccolingual dimensions of the alveolar ridge in all the patients in this study allowed implant insertion but with slight bony dehiscence exposing the crestal 2-3 threads of the implant fixture which necessitated simultaneous bone augmentation at the same time of the implant insertion using bone graft and titanium mesh (Benic \& Hammerle, 2014). The radiographic buccolingual width of the coronal third of the alveolar ridge ranges from 4 to $5 \mathrm{~mm}$ in all cases, and this was measured at a point $5 \mathrm{~mm}$ apical to the alveolar crest. While the radiographic buccolingual width of the apical third of the alveolar ridge ranges from 10 to $14 \mathrm{~mm}$ in all cases, and this was measured at a point $9 \mathrm{~mm}$ apical to the alveolar crest. All Patients were free from any systemic disease as evidenced by Burket's Oral Medicine health history questionnaire (Glick et al., 2008).

Exclusion criteria: Smokers (Susarla et al., 2008), patients with residual infection in the edentulous area or apparent infection in a neighboring tooth and patients with poor oral hygiene were excluded from the study. Moreover, vulnerable groups as pregnant females were also excluded from the study.

The nature of the study was explained to each patient and the patients were fully informed about the surgical procedure and the treatment alternatives. An informed consent was obtained from all participants prior to any study-related procedures.

The fourteen patients in this study were randomly divided into two groups; group one and group two by the flip of a coin. Group 1 (7 patients, test group) received dental implant simultaneously with alveolar ridge augmentation performed using customized titanium mesh (CTi Mem, Neobiotech, USA) and xenografts (Hypro-oss, Bioimplon, Germany) mixed with vitamin $\mathrm{D}_{3}$. Group 2 (7 patients, control group) received dental implant simultaneously with alveolar ridge augmentation performed using customized titanium mesh (CTi Mem, Neobiotech, USA) and xenografts (Hypro-oss,
Bioimplon, Germany) only without using vitamin $\mathrm{D}_{3}$ . In both groups, the bone graft covered the exposed coronal 2-3 threads of the implant fixture.

Preparation of vitamin $\mathrm{D}_{3}$ gel: Active vitamin $\mathrm{D}_{3}$ gel was prepared by pharmaceutical factory, Faculty of Pharmacy, Tanta University. Accurately weighted methyl cellulose was added to required amount of biocompatible solvent to prepare methyl cellulose gel. The mix was heated at $50{ }^{\circ} \mathrm{C}$ to $60{ }^{\circ} \mathrm{C}$ and shaken well with a mechanical shake to obtain a clear solution. Weighted mount of aqueous solution of vitamin $\mathrm{D}_{3}$ (active material manufactured by MUP company "medical union pharmaceuticals") was added to the previous solution and dissolved completely to obtain a homogenous gel which was loaded in sterile plastic syringes and stored in dry cool environment for use. The concentration of vitamin $\mathrm{D}_{3}$ gel was similar to concentration used in previous studies (Hong et al., 2015). Each 25ml of gel contains Vitamin $\mathrm{D}_{3}$ (80 I .U), Hydroxyl propyl methyl cellulose $(2 \mathrm{~g})$ and Water $(10 \mathrm{~g})$.

Preoperative evaluation: Preoperative analysis included complete patient history, clinical examination, clinical photographs and radiographic examination using the cone beam computed tomography (CBCT) to evaluate the alveolar ridge. Two weeks before the surgery, professional debridement and instructions in self-performed plaque control measures were delivered to all patients. Single surgery was performed to each patient throughout the study involving the implant insertion and alveolar ridge augmentation performed simultaneously. The same surgical steps and materials were used in both groups except the addition of vitamin $\mathrm{D}_{3}$ to the graft material in group 1 (test group) only. All surgeries were performed in the oral medicine and periodontology department faculty of dentistry, Ain Shams University. Surgical procedure (figure 1) : Patients were pre-medicated one hour before the surgery with amoxycillin $875 \mathrm{mg} /$ clavulanic acid $125 \mathrm{mg}$ orally" and Dexamethasone phosphate $8 \mathrm{mg}$ I.M. injection** (Di Stefano et al, 2009, Dasmah et $a l, 2012)$. All patients were also instructed to rinse 
with $0.1 \%$ Chlorhexidine gluconate ${ }^{* * *}$ for 2 minutes before starting the surgery.

Following local anaesthesia, crestal incision was performed slightly palatal to the alveolar crest and 2 vertical incisions were performed one tooth before and one tooth after the edentulous area thus at the end of the surgery the edges of the titanium mesh were not under the flap margins.

Full thickness mucoperiosteal flaps were elevated labially and palatally. Enough reflection at the labial aspect passing the mucogingival junction was very important to allow coronal advancement of the mucosa at the end of the surgery, tension-free adaptation of the wound margins, wound stability and primary intention closure of the surgical flap which are of primary importance for the prognosis of the regenerative procedures (Haney et al., 1993).

The alveolar bone was curetted by bone curette to remove any soft tissue remnants on the bone surface. Implant site preparation was then performed in routine fashion using the implant surgical kit drills (Neobiotech, IS implant, USA). Initially the pointed drill was used to locate the pathway of the fixture insertion, no more than $8 \mathrm{~mm}$ depth. The speed used was 1000-1200 rpm with torque 20NCM. At the same torque and speed, the pilot drill was then used drilling to the full length of the implant preparing the osteotomy followed by the final drill which was $3.0 \mathrm{~mm}$ diameter in all cases allowing implant insertion $3.5 \mathrm{~mm} \times 13 \mathrm{~mm}$ in all cases (Neo CMI implant, IS-II active fixture, Neo Biotech, USA). Implant insertion was then performed using the hand piece at $30 \mathrm{rpm}$ and $40 \mathrm{NCM}$ followed by torque wrench till the implant platform was flushing with the lingual alveolar crest in all cases. The implant stability quotient was then measured using the Osstell device (Osstell Mentor ${ }^{\circledR}$, integration diagnostics AB, Goteberg, Sweden).

All the implants after insertion suffered bony dehiscence exposing around 2-3 coronal threads of the implant fixture. Particulate xenograft was hydrated with saline in a sterile dappen dish for 10 minutes then used to cover the bony dehiscence and the whole labial bony plate after slight decortication with small round bur. The customized titanium mesh (CTi-Mem, Neobiotech) was then stabilized in place using the cover screw of the implant then its margins were burnished with large ball burnisher. For group 1 only, Vitamin $\mathrm{D}_{3}$ was added to the xenograft in the dappen dish before use.

Releasing periosteal incisions were performed at the labial flap to allow tension free adaptation of the wound margin and primary intension closure of the flap which is crucial for the regenerative bony procedures. Suturing was then performed using polypropylene 4/0 sutures (Assut sutures), starting with the crestal incisions followed by the vertical incisions.

Post-surgical medications and instructions: Antibiotic, anti-inflammatory and anti-edematous medications were prescribed for all patients. Antibiotic [Amoxycillin/ clavulanic acid orally ${ }^{* * * *}$; 1 tab every 12 hours for 7 days + Metronidazole orally $^{* * * * *} ; 1$ tab every 12 hours for 7 days], Antiinflammatory [Diclofenac potassium $50 \mathrm{mg}^{* * * * * * *}$; 1 tablet 3 times daily for 3 days], and Antiedematous [Chymotrypsin/trypsin ${ }^{* * * * * *} ; 1$ tablet 3 times daily for 5days]. Patients were instructed to use Chlorhexidine mouth wash twice daily for 2 weeks starting the second day following the surgery to reduce the risk of infection.

\footnotetext{
* Hibiotic $1 \mathrm{gm}$ tablets; Amoun pharmaceuticals

** Epidron ampoule 2ml; Eipico

*** Hexitolmouth wash; Adco pharmaceuticals

**** Hibiotic 1gm tablets; Amoun pharmaceuticals. Egypt

***** Flagyl $500 \mathrm{mg}$ tablets; Aventis.Egypt

****** Cataflam 50mg tab, Novartis. Egypt

******* Alphintern; Amoun pharmaceuticals. Egypt
} 
Patients were instructed not to wear any removable prosthesis after the surgery till the final prosthesis fabrication. For some cases, resin bonded Maryland bridges were fabricated for esthetic purposes

The titanium mesh was removed 4 months after implant insertion by removing the cover screw of the implant using single horizontal crestal incision then the healing abutment was placed. Two weeks later prosthetic steps started to fabricate porcelain fused to metal fixed prosthesis.

\section{Evaluation and measurement:}

Evaluation of the changes in buccolingual alveolar ridge width: This was performed using the cone beam computed tomography (CBCT) (I-CAT cone beam $3 \mathrm{~d}$ dental imaging system, imaging sciences international, Hatfield, Pa) at $120 \mathrm{KVp}$, $5 \mathrm{ma}$, exposure time $3-4 \mathrm{sec}$, slice $0.3 \mathrm{~mm}$, field of view 60-70mm.
The CBCT was performed twice throughout our study. The initial CBCT was performed before the implant placement by one week, while the follow up CBCT was performed 4 months after implant placement. Always, the follow up CBCT was performed after removing the titanium mesh to avoid any distortion in the image that may be applied with the metal of the mesh.

During planning for the present study, we decided that choosing a single point at the edentulous area to be measured before and after the ridge augmentation will not be accurate representative of the buccolingual ridge width changes and will not be easily reproducible. Different points in the same edentulous area may show different degrees of changes in the alveolar ridge width by time. Thus, on the same CBCT, 2 sagittal views were used for evaluation and at each sagittal view 3 buccolingual measures were taken. The first was $4 \mathrm{~mm}$ apical to the alveolar crest, the second was $8 \mathrm{~mm}$ apical

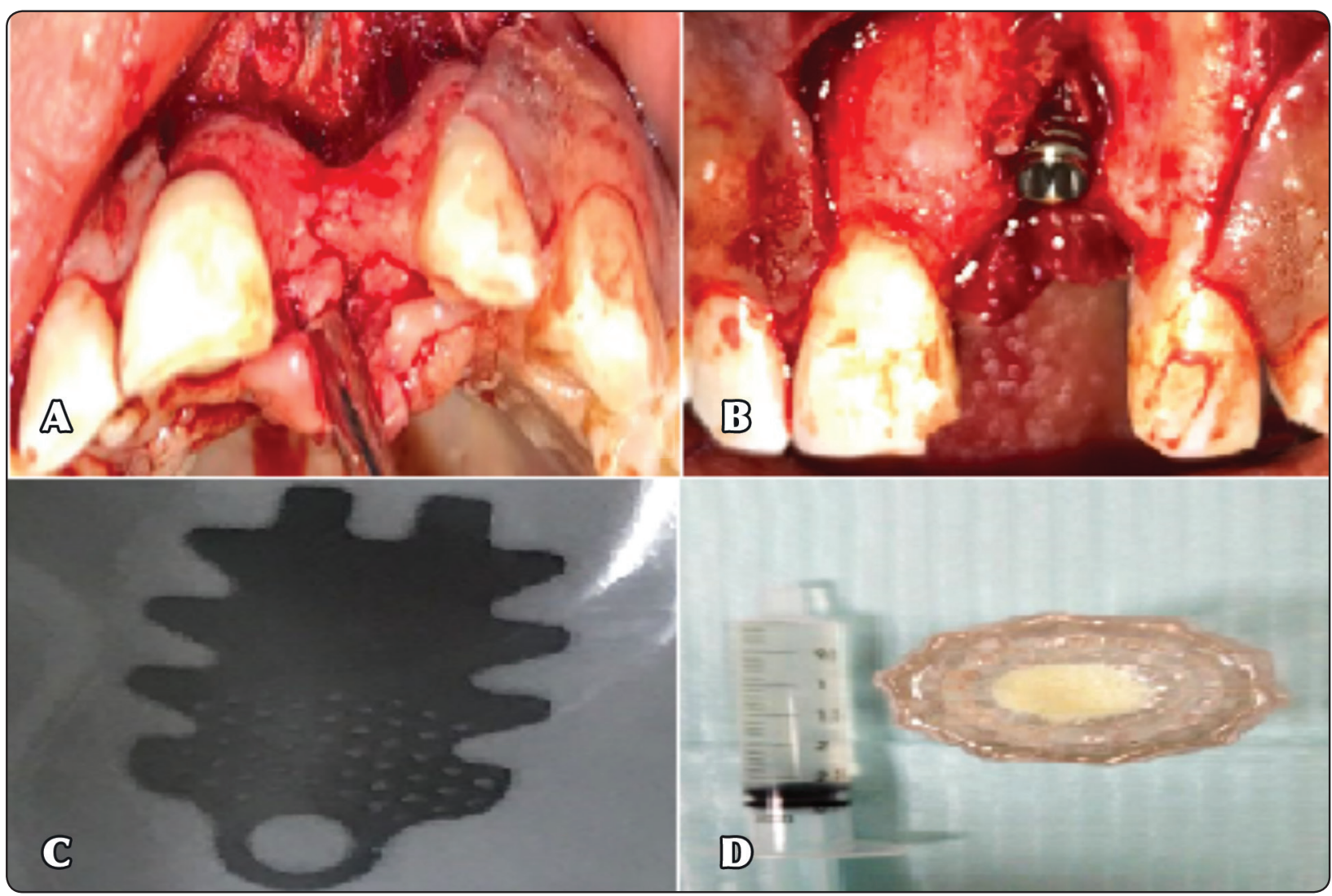




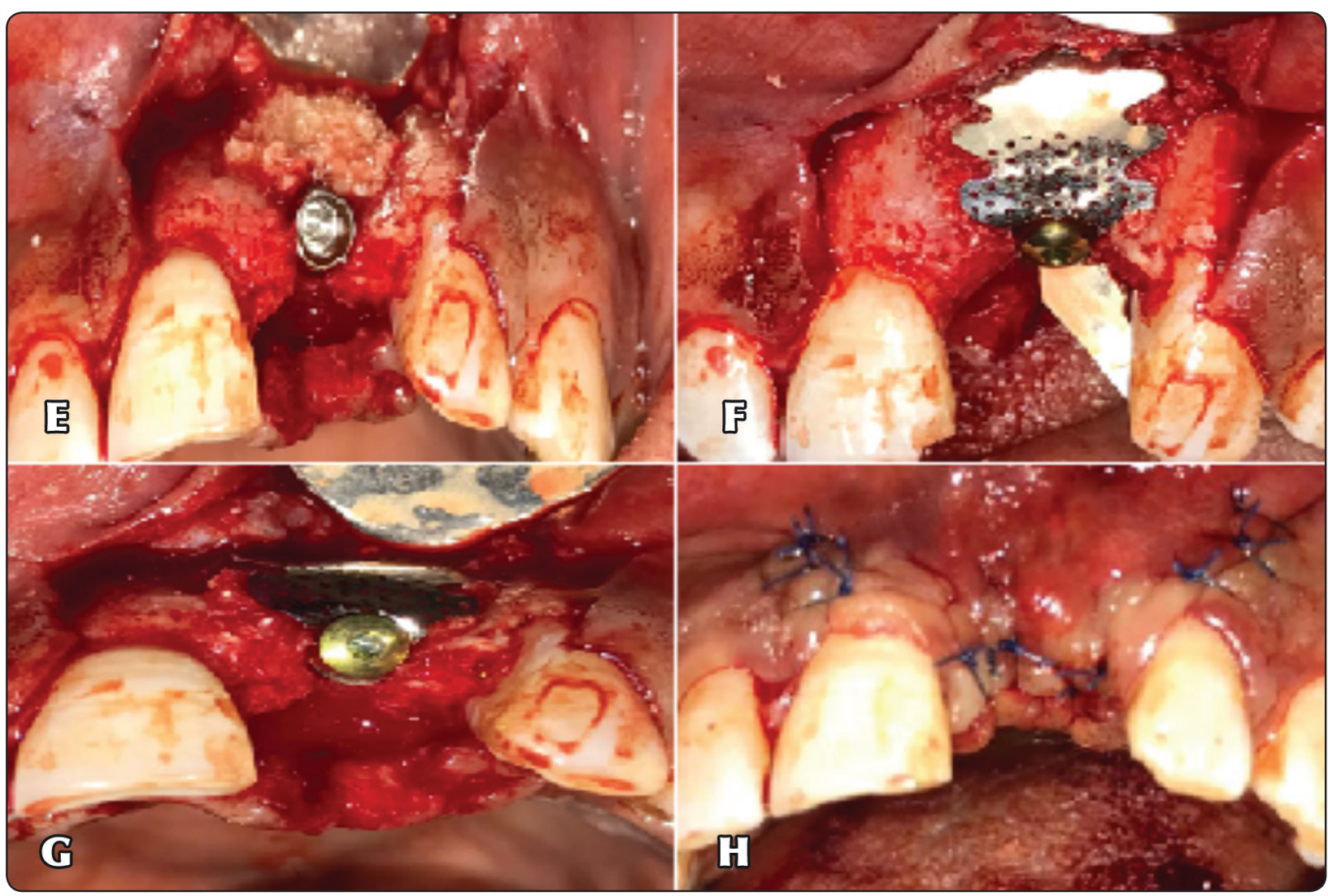

Fig. (1) A,B, implant placement in thin alveolar ridge with bony dehiscence.C,D, titanium mesh, bone graft \& vit D. E, Placement of graft. F,G mesh fixation. H, sututring

to the crest, and the third was $12 \mathrm{~mm}$ apical to the crest. Thus total 6 measures for the ridge buccolingual width for each patient at each occasion were taken then the average buccolingual width was calculated (figure 2). it should be noted here that all implants in the study were placed that the shoulder of the implant is flushing with the lingual alveolar crest, thus during the second CBCT measurements the implant shoulder was used as the fixed point that measurements can start from them. Evaluation of the implant stability: This was performed using Osstell Mentor ${ }^{\circledR}$ (integration diagnostics AB, Goteberg, Sweden) for the magnetic resonance frequency measurements. The smart peg was screwed to the implant fixture and tightened to around 5NCM. The transducer probe was aimed at the small magnet at the top of the smart peg at a distance of $2-3 \mathrm{~mm}$ and then held stable until the osstell showed the implant stability quotient value (ISQ).

The ISQ for each implant was evaluated twice throughout the study. The Baseline ISQ (ISQ1) was measured just after implant insertion the day of surgery and the follow up ISQ (ISQ2) was measured 4 months after implant insertion after removing the titanium mesh and just before healing abutment placement.

At each occasion, the ISQ was evaluated for every implant labially, lingually, mesially and distally, then the mean value was calculated.

\section{Statistical analysis}

Numerical data were explored for normality using Kolmogorov-Smirnov test of normality. Normally distributed (parametric data) were presented as mean, standard deviation (SD), and 95\% confidence 


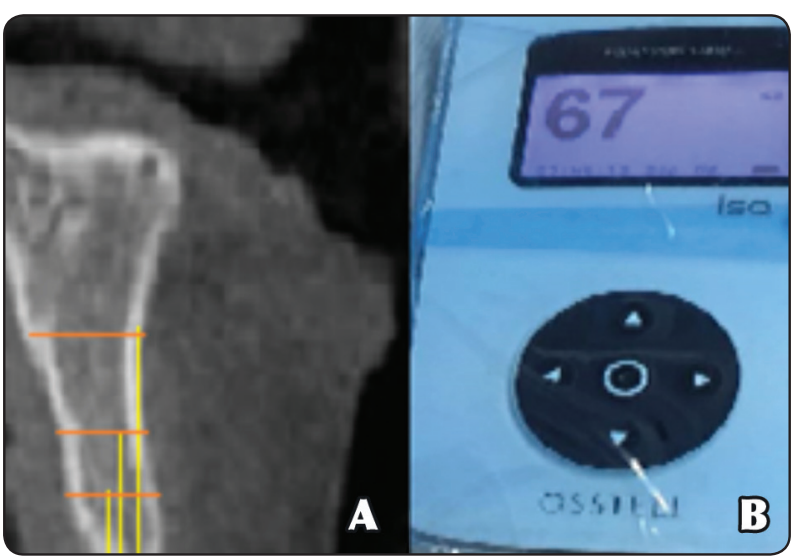

Fig. (2) A, buccolingual alveolar ridge assessment on CBCT at multiple points. B, implant stability assessment by OSSTELL.

intervals and were compared between groups using independent $t$ test (intergroup). Intragroup comparison was performed using paired $t$ test. The percent change was calculated using the formula:

Value after-value before X 100

Value before

The significance level was set at $p<0.05$. Statistical analysis was performed with SPSS 18.0 (Statistical Package for Scientific Studies, SPSS, Inc., Chicago, IL, USA) for Windows.

\section{RESULTS}

\section{Buccolingual (BL) alveolar ridge width :}

\section{a) Intra group comparison of values}

In group 1, a higher mean value was recorded after follow-up. The difference between initial and follow up value was statistically significant $(\mathrm{p}=0.00)$.

In group 2, a higher mean value was recorded after follow-up. The difference between initial and follow up value was statistically significant $(\mathrm{p}=0.00),($ Table 1, Fig.3)

\section{b) Inter group comparison of values}

Regarding initial BL width, a higher mean value was recorded in group1, with no statistically significant difference between groups $(\mathrm{p}=0.25)$.

Regarding Follow-up BL width, a higher mean value was recorded in group1, with a statistically significant difference between groups $(\mathrm{p}=0.00)$, (Table 2)

\section{c) Intergroup comparison of percent change}

Regarding the percent change in BL width, a higher mean percent increase was recorded in group1, with a statistically significant difference between groups $(\mathrm{p}=0.00) \quad$ (Table 3$)$

TABLE (1) Descriptive statistics and intra-group comparison of BL width (paired t test)

\begin{tabular}{|c|c|c|c|c|c|c|c|c|c|c|c|}
\hline & & & & & & & Differ & & & & \\
\hline & width & Mean & Dev & Error & & Std. & Std & $95 \%$ C.I & $95 \%$ C.I & $\mathrm{t}$ & $\mathrm{P}$ \\
\hline & Initial & 8.79 & .75 & .28 & & & & & & & \\
\hline & Follow up & 12.59 & 1.28 & .48 & & & & & & & \\
\hline & Initial & 8.33 & .65 & .25 & & & & & & & \\
\hline U2 & Follow up & 9.81 & .90 & .34 & $-1 .+7$ & 西 & .12 & -1.10 & -1.20 & נ12.J & .00 \\
\hline
\end{tabular}

Significance level $p \leq 0.05$, *significant 
TABLE (2) Descriptive statistics and inter-group comparison of BL width (independent t test)

\begin{tabular}{|c|c|c|c|c|c|c|c|c|c|c|}
\hline \multirow[b]{2}{*}{ BL width } & \multirow[b]{2}{*}{ Groups } & \multirow[b]{2}{*}{ Mean } & \multirow{2}{*}{$\begin{array}{l}\text { Std. } \\
\text { Dev }\end{array}$} & \multirow{2}{*}{$\begin{array}{c}\text { Std. } \\
\text { Error } \\
\text { Mean }\end{array}$} & \multicolumn{4}{|c|}{ Difference } & \multirow[b]{2}{*}{$\mathrm{t}$} & \multirow[b]{2}{*}{$\mathrm{P}$} \\
\hline & & & & & Mean & $\begin{array}{l}\text { Std } \\
\text { error }\end{array}$ & $\begin{array}{c}95 \% \text { C.I } \\
\text { Upper }\end{array}$ & $\begin{array}{l}\text { 95\% C.I } \\
\text { Lower }\end{array}$ & & \\
\hline \multirow{2}{*}{ Initial } & Gp1 & 8.79 & .75 & .28 & \multirow{2}{*}{.46} & \multirow{2}{*}{.38} & \multirow{2}{*}{-.37} & \multirow{2}{*}{1.28} & \multirow{2}{*}{1.21} & \multirow{2}{*}{$.25 \mathrm{~ns}$} \\
\hline & Gp 2 & 8.33 & .65 & .25 & & & & & & \\
\hline \multirow{2}{*}{ Follow up } & Gp1 & 12.59 & 1.28 & .48 & \multirow{2}{*}{2.77} & \multirow{2}{*}{.59} & \multirow{2}{*}{1.47} & \multirow{2}{*}{4.08} & \multirow{2}{*}{4.68} & \multirow{2}{*}{$0.00 *$} \\
\hline & Gp 2 & 9.81 & .90 & .34 & & & & & & \\
\hline
\end{tabular}

Significance level $p \leq 0.05$, *significant, $n s=n o n$-significant

TABLE (3) Descriptive statistics and inter-group comparison of percent change in BL width (independent t test)

\begin{tabular}{|c|c|c|c|c|c|c|c|c|c|c|}
\hline \multirow[b]{2}{*}{ BL width } & \multirow[b]{2}{*}{ Groups } & \multirow[b]{2}{*}{ Mean } & \multirow{2}{*}{$\begin{array}{l}\text { Std. } \\
\text { Dev }\end{array}$} & \multirow{2}{*}{$\begin{array}{l}\text { Std. Error } \\
\text { Mean }\end{array}$} & \multicolumn{4}{|c|}{ Difference } & \multirow[b]{2}{*}{$\mathrm{t}$} & \multirow[b]{2}{*}{$\mathrm{P}$} \\
\hline & & & & & Mean & $\begin{array}{l}\text { Std } \\
\text { error }\end{array}$ & $\begin{array}{l}\text { 95\% C.I } \\
\text { Upper }\end{array}$ & $\begin{array}{l}\text { 95\% C.I } \\
\text { Lower }\end{array}$ & & \\
\hline \multirow{2}{*}{$\begin{array}{l}\text { Percent } \\
\text { Change }\end{array}$} & Gp1 & 43.10 & 3.76 & 1.42 & \multirow{2}{*}{25.34} & \multirow{2}{*}{1.80} & \multirow{2}{*}{21.39} & \multirow{2}{*}{29.30} & \multirow{2}{*}{14.04} & \multirow{2}{*}{$.00^{*}$} \\
\hline & Gp 2 & 17.75 & 2.95 & 1.11 & & & & & & \\
\hline
\end{tabular}

Significance level $p \leq 0.05$, *significant

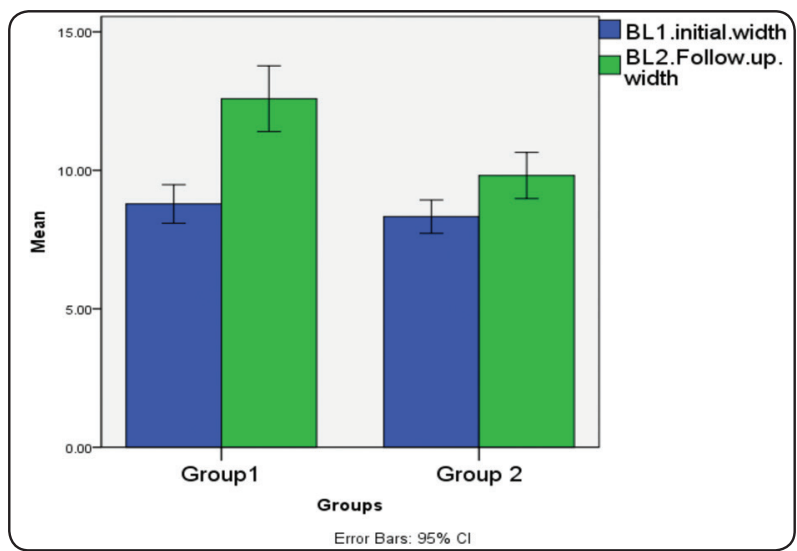

Fig. (3) Bar chart showing mean initial and follow-up BL width in group $1 \& 2$

\section{Implant stability ISQ:}

\section{a) Intra group comparison of values}

In group 1, a higher mean value was recorded after follow-up. The difference between initial and follow up value was statistically significant $(\mathrm{p}=0.00)$.

In group 2, a higher mean value was recorded after follow-up. The difference between initial and follow up value was statistically significant $(\mathrm{p}=0.01)$ (Table 4, fig 4)

\section{b) Inter group comparison of values}

Regarding primary ISQ, a higher mean value was recorded in group1, with no statistically significant difference between groups $(\mathrm{p}=0.73)$. 
Regarding secondary ISQ, a higher mean value was recorded in group1, with a statistically significant difference between groups $(\mathrm{p}=0.02)$, (Table 5)

\section{c) Intergroup comparison of percent change}

Regarding the percent change in ISQ, a higher mean percent increase was recorded in group1, with a statistically significant difference between groups $(\mathrm{p}=0.00),($ Table 6$)$

TABLE (4) Descriptive statistics and intra-group comparison of ISQ (paired t test)

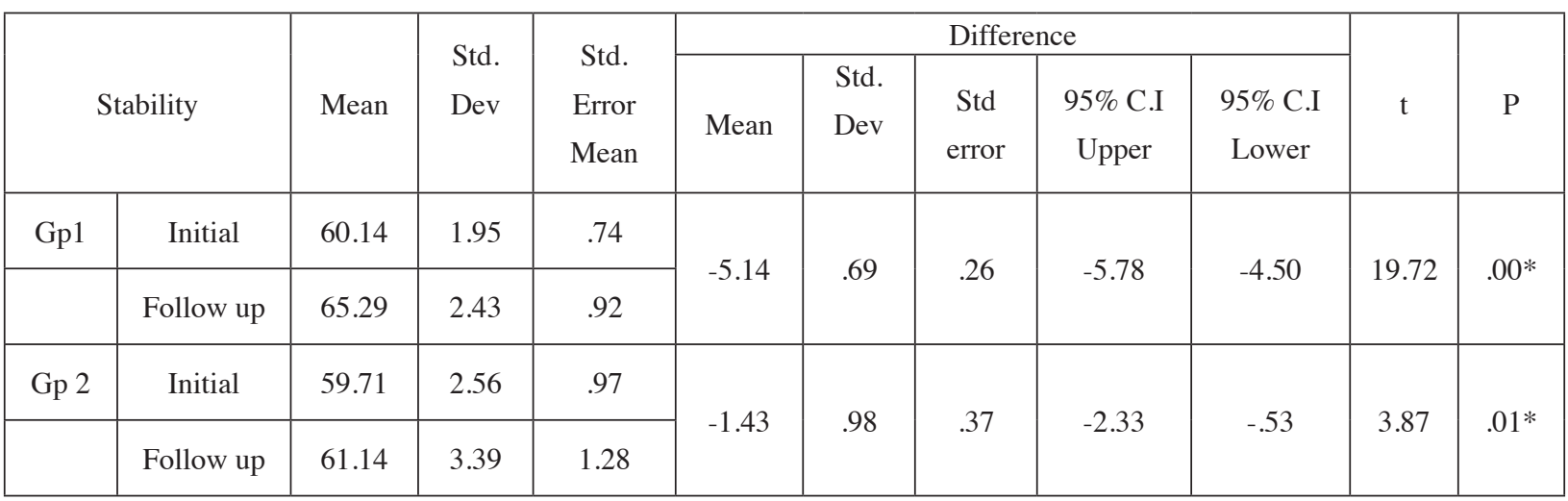

Significance level $p \leq 0.05$, *significant, $n s=n o n$-significant

TABLE (5) Descriptive statistics and inter-group comparison of values of stability (ISQ) (independent t test)

\begin{tabular}{|c|c|c|c|c|c|c|c|c|c|c|}
\hline \multirow{2}{*}{ ISQ Stability } & \multirow{2}{*}{ Groups } & \multirow{2}{*}{ Mean } & \multirow{2}{*}{$\begin{array}{l}\text { Std. } \\
\text { Dev }\end{array}$} & \multirow{2}{*}{$\begin{array}{l}\text { Std. } \\
\text { Error } \\
\text { Mean }\end{array}$} & \multicolumn{4}{|c|}{ Difference } & \multirow[b]{2}{*}{$\mathrm{t}$} & \multirow{2}{*}{$P$} \\
\hline & & & & & Mean & $\begin{array}{l}\text { Std } \\
\text { error }\end{array}$ & $\begin{array}{c}95 \% \text { C.I } \\
\text { Upper }\end{array}$ & $\begin{array}{l}\text { 95\% C.I } \\
\text { Lower }\end{array}$ & & \\
\hline \multirow{2}{*}{ Primary } & Gp1 & 60.14 & 1.95 & .74 & \multirow{2}{*}{.43 } & \multirow{2}{*}{1.22} & \multirow{2}{*}{-2.25} & \multirow{2}{*}{3.10} & \multirow{2}{*}{.35} & \multirow{2}{*}{$.73 \mathrm{n}$} \\
\hline & Gp 2 & 59.71 & 2.56 & .97 & & & & & & \\
\hline \multirow[t]{2}{*}{ Secondary } & Gp1 & 65.29 & 2.43 & .92 & \multirow{2}{*}{4.14} & \multirow{2}{*}{1.58} & \multirow{2}{*}{.67} & \multirow{2}{*}{7.62} & 2.63 & \multirow{2}{*}{$.02 *$} \\
\hline & Gp 2 & 61.14 & 3.39 & 1.28 & & & & & & \\
\hline
\end{tabular}

Significance level $p \leq 0.05$, *significant, $n s=n o n$-significant

TABLE (6) Descriptive statistics and inter-group comparison of percent change of stability (ISQ) (independent $t$ test)

\begin{tabular}{|c|c|c|c|c|c|c|c|c|c|c|}
\hline \multirow[b]{2}{*}{ ISQ Stability } & \multirow[b]{2}{*}{ Groups } & \multirow[b]{2}{*}{ Mean } & \multirow{2}{*}{$\begin{array}{l}\text { Std. } \\
\text { Dev }\end{array}$} & \multirow{2}{*}{$\begin{array}{c}\text { Std. Error } \\
\text { Mean }\end{array}$} & \multicolumn{4}{|c|}{ Difference } & \multirow[b]{2}{*}{$\mathrm{t}$} & \multirow[b]{2}{*}{$\mathrm{P}$} \\
\hline & & & & & Mean & $\begin{array}{l}\text { Std } \\
\text { error }\end{array}$ & $\begin{array}{l}\text { 95\% C.I } \\
\text { Upper }\end{array}$ & $\begin{array}{l}\text { 95\% C.I } \\
\text { Lower }\end{array}$ & & \\
\hline \multirow{2}{*}{$\begin{array}{l}\text { Percent } \\
\text { Change }\end{array}$} & Gp1 & 8.54 & 1.01 & .38 & \multirow{2}{*}{6.19} & \multirow{2}{*}{.69} & \multirow{2}{*}{4.66} & \multirow{2}{*}{7.72} & \multirow{2}{*}{8.95} & \multirow{2}{*}{$.00 *$} \\
\hline & Gp 2 & 2.35 & 1.53 & .58 & & & & & & \\
\hline
\end{tabular}

Significance level $p \leq 0.05$, *significant 


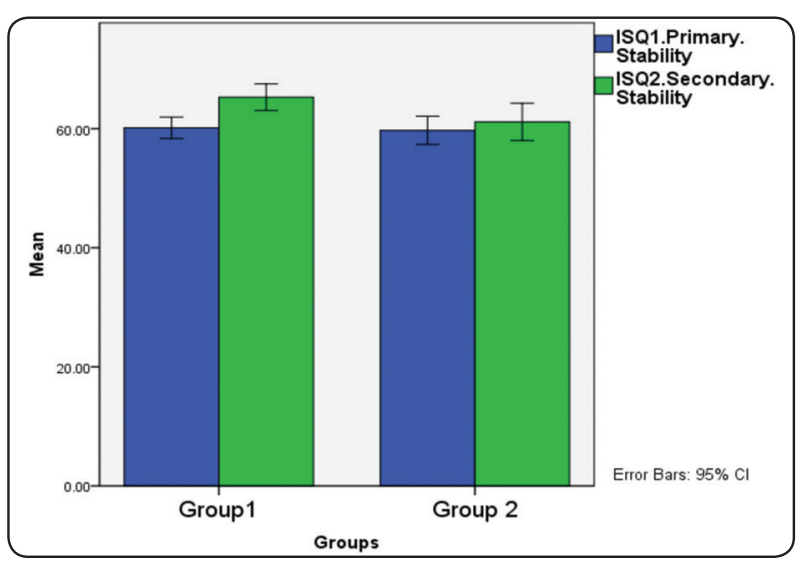

Fig. (4) Bar chart showing mean primary and secondary stability (ISQ) in group $1 \& 2$

\section{DISCUSSION}

Alveolar ridge resorption following tooth extraction is an inevitable process that affects the available alveolar bone quantity for implant placement. A sufficient volume of bone at an edentulous site is crucial to expect long term good prognosis of dental implants (Barewal et al 2003, Rocchietta et al 2008).

In the present study, the combined single surgery approach was selected which involves simultaneous bone grafting and implant placement. Many authors support the combined surgery approach rather than the staged approach (Nystrom et al 2004, Van Der Meij 2005). This combined single surgery approach saves time, helps the patient to avoid performing two surgeries and according to many authors has the advantage of decreasing the resorption by time of the grafted bone, since most of the resorption of the graft occurs soon after grafting and the bone around functioning dental implants could be preserved (Kearns et al 1997, Verhoeven et al 2000).

Postoperative antibiotics following regenerative techniques with bone grafts and/or barrier membranes for a period varying from three to ten days were recommended by several authors to minimize complications (Jensen \& Sindet Pedersen, 1991; Buser et al., 1996; Fugazzotto, 1997; Misch, 1997).
In the present study, similar cases having maxillary anterior edentulous area were included thus nearly the same bone quality and density in all cases. Previous studies showed that implant stability differs among various bone qualities and densities. (Martinez et al 2001, Sennerby \& Meredith 2008).

Evaluation of implant stability in our study was performed with resonance frequency analysis (RFA) which is a reliable, easy, and noninvasive technique (Meredith 1998, Kahraman et al 2009) and it was performed using osstell ${ }^{\circledR}$ device (Integration Diagnostics, Göteborg, Sweden).

All cases in the present work were suffering bony dehiscence defect after implantation and were managed using particulate xenogenic bone graft (in addition to vitamin D in group 1) and titanium mesh. This was according to Benic and Hammerle suggested management for different bony defects around dental implants in 2014.

Customized porous titanium mesh was selected to be used in this study as a containment system for the bone graft, its rigidity allows space maintenance and prevention of flap collapse (Buser et al 1996; Donos et al 2002; Eisig et al 2003; Van Steenberghe et al 2003). Titanium is a highly biocompatible metal with numerous applications in oral surgery (Zablotsky et al 1991; Degidi et al 2003). Titanium meshes had been used widely in many previous studies and lead to successful bone regenerative results. (Von Arx et al 1996; Boyne 1997; Schopper et al 2001)

The use of titanium mesh rather than resorbable barrier membranes in the present study was based on previous studies which showed that resorbable membranes lack stability, lack rigidity, may show antigenicity. Moreover, resorbable membranes suffers early resorption while titanium meshes keep the space till the time of removal thus maximize bone gain. (Lekholm et al 1993; Black et al 1994; Becker et al 1996; Simion et al 1996; Zitzmann et al 1997; Lundgren et al 1998) 
Moreover, porous titanium mesh was preferred over non-resorbable titanium reinforced polytetrafluoroethylene (PTFE) membranes in this study since the pores in the mesh may play a role in enhancing graft nutrition, metabolic exchange and showed better tissue integration. (Von Arx et al 1998)

The most common complication reported in literature associated with the use of titanium meshes was the mesh exposure and wound dehiscence. This was usually related to irritation of the mucosal flap by the sharp edges of the mesh obtained during mesh trimming according to the defect shape (Becker et al 1996; Watzinger et al 2000). This complication was avoided in our study by selecting a pre-contoured and pre-trimmed titanium mesh, already adjusted and customized to the defect shape and compatible with the implant system used thus no need for scissor cutting and no possibility of producing sharp edges.

Owing to the physicochemical characteristics of xenografts that are similar to human bone, xenografts were selected to be used in this study being excellent osteoconductive material and used successfully in many regenerative procedures (Hallman \& Thor 2008; Di stefano et al 2009; Ohayon 2011; Pagliani et al 2012). Many authors reported that xenografts required long time before graft resorption and substitution by newly formed bone. (Piatelli et al 1999; Hallman et al 2001; Hallman et al 2002). Thus, many studies are being carried out nowadays trying to enhance the resorbability of the xenografts and the creep substitution of the graft material by new bone formation through adding biologic materials to the xenografts that can affect the osteoblastic-osteoclastic functions.

In our study, vitamin $\mathrm{D}_{3}$ was mixed with the xenograft in an attempt to improve the biologic properties of the graft taking in considerations the previously reported actions of vitamin $\mathrm{D}_{3}$ on osteoblastic-osteoclastic activities. Previous literature reported that vitamin $\mathrm{D}_{3}$ receptors (VDRs) are available in most body cells which means that vitamin $\mathrm{D}_{3}$ can exert diverse actions on different cells. (Landfield et al 1991; Garcion et al 1997; Becker et al 2005). Moreover, many studies proved that vitamin $\mathrm{D}_{3}$ is a potent regulator of osteoclasticosteoblastic actions. (Kraichely \& MacDonald 1998; Misof et al 2003; Rapuri et al 2007). Thus it was tempting to examine vitamin $\mathrm{D}_{3}$ ability in enhancing bone augmentation around dental implants specially that to the best of our knowledge most of the previous studies on vitamin $D_{3}$ and alveolar bone regeneration were on animals and showed much diversity in their results.

Regarding the results of our study, in both groups a higher mean value of the alveolar ridge buccolingual width was recorded at the follow up (4 months after augmentation) in compare to the base line value. This was in accordance with many previous studies that showed that titanium mesh in combination with particulate bone graft specially xenografts is a successful modality for alveolar ridge augmentation and results in predicable outcomes with new bone formation. (Von Arx et al 1998; Hallman and Thor 2008; Pagliani et al 2012). No statistical significant difference was noticed between the baseline buccolingual widths in both groups since strict inclusion criteria were followed during patient selection.

A statistically significant higher mean percent increase in the buccolingual ridge width in group 1 in comparison to group 2 was noticed. This was in accordance with previous study by Hsiang -His Hong et al 2014 that showed that locally-applied active vitamin $D_{3}$ has a positive effect on bone regeneration, accelerating new bone formation and being a regulator of both bone formation and bone resorption (Kraichely \& Mac Donald 1998; Misof et al 2003; Rapuri et al 2007) through VDRs that are present in most body cells (Landfield et al 1991; Garcion et al 1997; Becker et al 2005).

Regarding the initial baseline ISQ values in this study, no significant difference was noted between groups since all cases were in the maxillary anterior 
region, same implant size and design, same operative technique and nearly same bone availability, thus, all factors affecting the primary stability according to the literature were standardized (Sennerby \& Meredith 2008).

Simunek et al 2012 showed that implants with low primary stability showed increase of ISQ during the healing period. In both groups, an increase in the ISQ mean value was recorded 4 months after implant insertion which was in accordance with Sargolzaie et al 2019 who showed that for all bone types, implant stability values decreased initially during the first postoperative month then increase by month 3 after implantation .

Comparing the follow up ISQ in both groups (measured 4 months after implant insertion); higher mean value was recorded in group 1. Moreover, higher percent increase by time was noticed in group 1 in comparison to group 2 .

This may be related to the vitamin $\mathrm{D}_{3}$ used in group 1 , as previous studies showed that vitamin $\mathrm{D}_{3}$ can play a role in enhancing bone density and improving implant stability (Dvorak et al 2012; Zhou et al 2012; Liu et al 2014; Hsiang-Hsi Hong et al 2015).

Many authors support the idea that enhanced bone density leads to increased implant stability (Friberg et al 2003, Ikumi et al 2005, Turkyilmaz. et al 2006). Although, a study in 2003 showed no relation between implant stability and bone quality (Beer et al 2003) and another review article reported that the relationship between implant stability and the density of alveolar bone were not consistent, and concluded that this may be related to the different methodologies, and techniques of stability assessments (Miri et al 2017).

A recent study in 2019 reported that reaching a certain conclusion about the effect of bone density on implant stability may be difficult as many factors may affect the stability of dental implant (Sargolzaie et al 2019).

\section{CONCLUSION}

Within the limitations of this study, we can conclude that Vitamin D enhanced the bone formation when mixed with xenografts in alveolar ridge augmentation surgeries. Moreover, it played a role in improving implant stability. Further studies should be carried out in the future to evaluate the effect of vitamin D on the quality of the newly formed bone histologically and evaluate the effect of vitamin $\mathrm{D}$ on different bone qualities.

\section{REFERENCES}

- Araujo MG, Sukekava F, Wennström JL, Lindhe J. Ridge alterations following implant placement in fresh extraction sockets: an experimental study in the dog. J Clin Periodontol 2005; 32:645-652.

- Araujo MG, Lindhe J. Dimensional ridge alterations following tooth extraction. An experimental study in the dog. J Clin Periodontol 2005; 32:212-218.

- $\quad$ Artzi Z, Dayan D, Alpern Y, Nemcovsky CE. Vertical ridge augmentation using xenogenic material supported by a configured titanium mesh: clinicohistopathologic and histochemical study. Int J Oral Maxillofac Implants. 2003;18:440-446.

- Barewal RM, Oates TW, Meredith N, Cochran DL. Resonance frequency measurement of implant stability in vivo on implants with a sandblasted and acid-etched surface. Int J Oral Maxillofac Implants 2003; 18:641-651.

- Barone A, Aldini NN, Fini M, Giardino R, Calvo Guirado JL, Covani U. Xenograft versus extraction alone for ridge preservation after tooth removal: a clinical and histomorphometric study. J Periodontol 2008; 79:13701377.

- $\quad$ Becker W, Becker B, Mellonig J. A prospective multicenter study evaluating periodontal regeneration for class II furcation invasions and infrabony defects after treatment with a bioabsorbable barrier membrane: 1-year results. J Periodontol, 1996; 67:641.

- $\quad$ Becker A, Eyles DW, McGrath JJ, Grecksch G. Transient prenatal vitamin D deficiency is associated with subtle alterations in learning and memory functions in adult rats. Behav Brain Res 2005; 161: 306-12.

- Beer A, Gahleitner A, Holm A, Tschabitscher M, Homolka P. Correlation of insertion torques with bone mineral 
density from dental quantitative $\mathrm{CT}$ in the mandible. Clin Oral Implants Res 2003;14:616-20.

- Bell RB, Blakey GH, White RP, Hillebrand DG, Molina A. Staged reconstruction of the severely atrophic mandible with autogenous bone graft and endosteal implants. J Oral Maxillofac Surg 2002;60:1135-41.

- Benic GI \& Hammerle CHF. Horizontal bone augmentation by means of guided bone regeneration. 2014; Periodontology 2000,66, , 13-40.

- Bikle DD. Vitamin D regulated keratinocyte differentiation. Journal of Cellular Biochemistry 2004; 92: 436-444.

- $\quad$ Black BS, Gher ME, Sandifer JB. Comparative study of collagen and expanded polytetrafluroethylene membranes in the treatment of human class II furcation defects. J Periodontol 1994; 65:598.

- $\quad$ Boyne PJ, Cole MD, Stringer D, Shafqat JP. A technique for osseous restoration of deficient edentulous maxillary ridges. J Oral Maxillofac Surg. 1985; 43:87-91.

- Boyne PJ: Reconstruction of the Maxilla and Mandible. Quintessence, Inc, Hanover Park, IL, 1997; 37-52

- Brumbaugh PF, Speer DP, Pitt MJ. 1 alpha, 25-Dihydroxyvitamin D3 a metabolite of vitamin D that promotes bone repair. Am J Pathol. 1982; 106: 171-9.

- $\quad$ Buser D, Dula K, Hirt HP, Schenk RK. Lateral ridge augmentation using autografts and barrier membranes: A clinical study with 40 partially edentulous patients. Int J Oral Maxillofac Surg 1996;54:420-432.

- Chapuy MC1, Arlot ME, Duboeuf F, Brun J, Crouzet B, Arnaud S, Delmas PD, Meunier PJ. Vitamin D3 and calcium to prevent hip fractures in the elderly women. $\mathrm{N}$ Engl J Med. 1992; 327: 1637-42.

- Chiapasco M, Zaniboni M, Boisco M. Augmentation procedures for the rehabilitation of deficient edentulous ridges with oral implants. Clin Oral Implants Res 2006;17(Suppl. 2):136-59.

- Clementini M, Morlupi A, Agrestini C, Barlattani A. Immediate versus delayed positioning of dental implants in guided bone regeneration or onlay graft regenerated areas: a systematic review. Int J Oral Maxillofac Surg. $2013 ; 42(5): 643-50$

- Dasmah A, Thor A, Ekestubbe A, Sennerby L, Rasmusson L. Particulate vs. block bone grafts: three-dimensional changes in graft volume after reconstruction of the atrophic maxilla, a 2-year radiographic follow-up. J Craniomaxillo-fac-Surg. 2012 Dec;40(8):654-9.

- Dawson-Hughes B1, Harris SS, Krall EA, Dallal GE. Effect of calcium and vitamin D supplementation on bone density in men and women 65 years of age or older. N Engl J Med. 1997; 337: 670-6.

- Di Stefano DA, Artese L, Iezz G, Piattelli A, Pagnutti S, Piccirilli M, Perrotti V. Alveolar ridge regeneration with equine spongy bone: a clinical, histological, and immunohistochemical case series. Clin Implant Dent Relat Res. 2009 ;11(2):90-100.

- Degidi M, Scarano A, Piattelli A. Regeneration of the alveolar crest using titanium micromesh with autologous bone and a resorbable membrane. J Oral Implantol 2003; 29:86.

- Dekel S, Salama R, Edelstein S. The effect of vitamin D and its metabolites on fracture repair in chicks. Clin Sci (Lond). 1983; 65: 429-36.

- Delgado-Martínez AD, Martínez ME, Carrascal MT, Rodríguez-Avial M, Munuera L. Effect of 25-OH-vitamin D on fracture healing in elderly rats. J Orthop Res. 1998; 16: 650-3.

- DeLuca HF. Overview of general physiologic features and functions of vitamin D. Am J Clin Nutr, 80(Suppl) 2004; 1689S-96S.

- Donos N, Kostopoulos L, Karring T. Alveolar ridge augmentation using a resorbable copolymer membrane and autogenous bone grafts: An experimental study in the rat. Clin Oral Implants Res , 2002; 13:203.

- Donos N, Mardas N, Chadha V. Clinical outcomes of implants following lateral bone augmentation: systematic assessment of available options (barrier membranes, bone grafts, split osteotomy). J Clin Periodontol 2008;35(8 Suppl.):173-202.

- Dvorak G, Fugl A, Watzek G. Impact of dietary vitamin $\mathrm{D}$ on osseointegration in the ovariectomized rat. Clin Oral Implants Res. 2012;23:1308-1313.

- $\quad$ Eisig SB, Ho V, Kraut R, Lalor . Alveolar ridge augmentation using titanium micromesh: An experimental study in dogs. J Oral Maxillofac Surg 2003; 61:347.

- $\quad$ Friberg B, Jisander S, Widmark G, Lundgren A, Ivanoff CJ, Sennerby L. One-year prospective three-center study comparing the outcome of a "soft bone implant" (prototype Mk IV) and the standard Brånemark implant. Clin Implant Dent Relat Res 2003;5:71-7. 
- Fugazzotto PA. Success and failure rates of osseointegrated implants in function in regenerated bone for 6 to 51 months: a preliminary report. International Journal of Oral and Maxillofacial Implants 1997; 12: 17-24.

- Gallagher JC, Goldgar D. Treatment of postmenopausal osteoporosis with high doses of synthetic calcitriol. A randomized controlled study. Ann Intern Med. 1990; 113: 649-55.

- Garcion E, Nataf S, Berod A, Darcy F, Brachet P. 1,25Dihydroxyvitamin D3 inhibits the expression of inducible nitric oxide synthase in rat central nervous system during experimental allergic encephalomyelitis. Brain Res Mol Brain Res 1997; 45: 255-67.

- Glick M, Greenberg MS, Ship JA: Introduction to Oral Medicine and Oral Diagnosis: Evaluation of the dental patient. In Burket s oral medicine. eleventh ed, Greenberg MS, Glick M, Ship JA. 2008. BC DECKER INC. Hamilton, pp 1-16.

- Gogolewski S, Gorna K, Turner AS. Regeneration of bicortical defects in the iliac crest of estrogen-deficient sheep, using new biodegradable polyurethane bone graft substitutes. J Biomed Mater Res A. 2006; 77: 802-10.

- Hallman M, Lundgren S, Sennerby L. Histologic analysis of clinical biopsies taken after 6 months and 3-years after maxillary sinus floor augmentation with $80 \%$ bovine hydroxyapatite and $20 \%$ autogenous bone mixed with fibrin glue. Clin Implant Dent Relat Res 2001; 2:87-96.

- Hallman M, Sennerby L, Lundgren S. A clinical and histologic evaluation of implant integration in the posterior maxilla after sinus floor augmentation with autogenous bone, bovine hydroxyapatite or a 20:80 mixture. Int J Oral Maxillofac Implants 2002; 17:635-643.

- Hallman M, Thor A. Bone substitutes and growth factors as an alternative/complement to autogenous bone for grafting in implant dentistry. Periodontol 2000 2008; 47:172-192.

- Haney JM, Nilveus RE, McMillan PJ, and Wikesjo UM. Periodontal repair in dogs: expanded polytetrafluoroethylene barrier membranes support wound stabilization and enhance bone regeneration. Journal of Periodontology . 1993; 64, no. 9: 883-890.

- Hewison M , Burke F, Evans KN, Lammas DA, Sansom DM, Liu P, Modlin RL \& Adams JS. Extra-renal 25-hydroxyvitamin D3-1alpha-hydroxylase in human health and disease. Journal of Steroid Biochemistry and Molecular Biology 2007; 103: 316-321.
- Holick MF. Vitamin D. In Modern nutrition in health and disease. 10th edition. Shrils M.et al. (eds). Baltimore, MA: Lippincott Williams and Wilkins, pp. 329-45. 2005a

- Holick MF. Vitamin D deficiency. N Engl J Med. 2007;357:266-281.

- Hong HH1, Chou TA, Yang JC, Chang CJ.The potential effects of cholecalciferol on bone regeneration in dogs. Clin Oral Implants Res. 2012; 23: 1187-92.

- Hong HH, Yen TH, Hong A, Chou TA. Association of vitamin D3 with alveolar bone regeneration in dogs. Journal of cellular and molecular medicine. $2015 ; 19(6)$ :1208-17.

- Hsiang-Hsi Hong, Tzung-Hai Yen , Adrienne Hong, TingAn Chou. Association of vitamin D3 with alveolar bone regeneration in dogs. J. Cell. Mol. Med. Vol 19, No 6, 2015 pp. $1208-1217$

- $\quad$ Ikumi N, Tsutsumi S. Assessment of correlation between computerized tomography values of the bone and cutting torque values at implant placement: A clinical study. Int J Oral Maxillofac Implants 2005;20:253-60.

- Jemt T, Lekholm U. Measurements of buccal tissue volumes at single-implant restorations after local bone grafting in maxillas: a 3-year clinical prospective study case series. Clin Implant Dent Relat Res 2003;5:63-70.

- Jensen J , Sindet-Pedersen S. Autogenous mandibular bone grafts and osseointegrated implants for reconstruction of the severely atrophied maxilla: a preliminary report. J Oral Maxillofac Surg 1991;49:1277-1287

- Kahraman S, Bal BT, Asar NV, Turkyilmaz I, Tözüm TF. Clinical study on the insertion torque and wireless resonance frequency analysis in the assessment of torque capacity and stability of self-tapping dental implants. J Oral Rehabil 2009;36:755-61.

- Kearns G, Perrott DH, Sharma A, Kaban LB, Vargervik K. Placement of endosseous implants in grafted alveolar clefts. Cleft Palate Craniofac J 1997; 34:520-5.

- Kraichely DM, MacDonald PN. Transcriptional activation through the vitamin D receptor in osteoblasts. Front Biosci 1998; 3: 821-33.

- Kumar PT, Antony S, Nandhu MS. Vitamin D3 restores altered cholinergic and insulin receptor expression in the cerebral cortex and muscarinic M3 receptor expression in pancreatic islets of streptozotocin induced diabetic rats. J Nutr Biochem. 2011;22:418-425. 
- Landfield PW, Applegate MD, Schmitzer-Osborne SE, Naylor CE. Phosphate/calcium alterations in the first stages of Alzheimer's disease: implications for etiology and pathogenesis. J Neurol Sci 1991; 106: 221-9.

- Lehmann B \& Meurer M. Extrarenal sites of calcitriol synthesis: the particular role of the skin. Recent Results in Cancer Research 2003; 164: 135-145.

- Lekholm U, Becker W, Dahlin C, Becker B, Donath K, Morrison E. The role of early versus late removal of GTAM membrane on bone formation at oral implants placed into immediate extraction sockets. Clin Oral Implants Res 1993; 4:121

- Lekholm U, Gunne J, Henry P, Higuchi K, Linden U, Bergstrom C, van Steenberghe D. Survival of the Bra ${ }^{\circ}$ nemark implant in partially edentulous jaws: a 10-year prospective multicenter study. Int J Oral Maxillofac Implants 1999;14:639-45.

- Leonhardt A, Grondahl K, Bergstrom C, Lekholm U. Long-term follow-up of osseointegrated titanium implants using clinical, radiographic and microbiological parameters. Clin Oral Implants Res 2002;13:127-32.

- $\quad$ Li YC1, Amling M, Pirro AE, Priemel M, Meuse J, Baron R, Delling G, Demay MB Normalization of mineral ion homeostasis by dietary means prevents hyperparathyroidism, rickets, and osteomalacia, but not alopecia in vitamin D receptor-ablated mice. Endocrinology. 1998;139:4391-4396.

- Lima LL, Cesar Neto JB, Cayana EG. Parathyroid hormone (1-34) compensates the negative effect of smoking around implants. Clin Oral Implants 2013.

- Lips P. Vitamin D physiology. Prog Biophys Mol Biol. 2006;92:4-8.

- $\quad$ Liu W, Zhang S, Zhao D. Vitamin D supplementation enhances the fixation of titanium implants in chronic kidney disease mice. PLoS One. 2014;9: e95689.

- $\quad$ Lizuka T, Smolka W, Hallermann W, Merickse- Stern R. Extensive augmentation of the alveolar ridge using autogenous calvarial split bone grafts for dental rehabilitation. Clin Oral Implants Res 2004;15:607-15.

- Lundgren S, Nystro“m E, Nilson H, Gunne J, Lindhagen O. Bone grafting to the maxillary sinuses, nasal floor and anterior maxilla in the atrophic edentulous maxilla. Int $\mathbf{J}$ Oral Maxillofac Surg 1997;26:428-34.

- Lundgren AK, Sennerby L, Lundgren D. Guided jaw bone regeneration using an experimental rabbit model. Int J Oral Maxillofac Surg 1998; 27:135.
- MacLaughlin JA, Anderson RR, Holick MF.. Spectral character of sunlight modulates photosynthesis of previtamin D3 and its photoisomers in human skin. Science, 1982; 216:1001-3.

- Martinez H, Davarpanah M, Missika P, Celletti R, Lazzara R. Optimal implant stabilization in low density bone. Clin Oral Implants Res 2001;12:423-32.

- McGrath CJ, Schepers SH, Blijdorp PA, Hoppenreijs TJ, Erbe M. Simultaneous placement of endosteal implants and mandibular onlay grafting for treatment of the atrophic mandible. A preliminary report. Int J Oral Maxillofac Surg 1996;25:184-8.

- Meredith N. Assessment of implant stability as a prognostic determinant. Int J Prosthodont 1998;11:491-501.

- Miri R, Shirzadeh A, Kermani H, Khajavi A. Relationship and changes of primary and secondary stability in dental implants: a review. Int J Contemp Dent Med Rev 2017.

- Misch, CM. Comparison of intraoral donor sites for onlay grafting prior to implant placement. International Journal of Oral and Maxillofacial Implants 1997, 12: 767-776.

- Misof BM , Roschger P, Tesch W, Baldock PA, Valenta A, Messmer P, Eisman JA, Boskey AL, Gardiner EM, Fratzl $\mathrm{P}$, Klaushofer K.Targeted overexpression of vitamin D receptor in osteoblasts increases calcium concentration without affecting structural properties of bone mineral crystals. Calcif Tissue Int 2003; 73: 251.

- Miyahara T1, Simoura T, Osahune N, Uchida Y, Sakuma T, Nemoto N, Kozakai A, Takamura T, Yamazaki R, Higuchi S, Chiba H, Iba K, Sawada N. A highly potent 26,27-Hexafluoro-1a,25-dihydroxyvitamin D3 on calcification in SV40- transformed human fetal osteoblastic cells. Calcif Tissue Int. 2002; 70: 488-95.

- Nystrom E, Ahlqvist J, Gunne J, Kahnberg KE. 10-year follow-up of onlay bone grafts and implants in severely resorbed maxillae. Int J Oral Maxillofac Surg 2004;33:25862.

- $\quad$ Ohayon L. Ridge enlargement using deproteinized bovine bone and a bioresorbable collagen membrane: a tomodensitometric, histologic, and histomorphometric analysis. Int J Periodontics Restorative Dent. 2011 Jun;31(3):237-45.

- Omeroğlu H1, Ateş Y, Akkuş O, Korkusuz F, Biçimoğlu A, Akkaş N.Biomechanical analysis of the effects of single high-dose vitamin D3 on fracture healing in a healthy rabbit model. Arch Orthop Trauma Surg. 1997; 116: 271-4. 
- Pagliani L, Andersson P, Lanza M, Nappo A, Verrocchi D, Volpe S, Sennerby L. A collagenated porcine bone substitute for augmentation at Neoss implant sites: a prospective 1-year multicenter case series study with histology. Clin Implant Dent Relat Res. 2012 Oct;14(5):746-58.

- Piattelli M, Favero GA, Scarano A, Orsini G, Piattelli A. Bone reactions to anorganic bovine bone (Bio-Oss) used in sinus augmnetation procedures: a histologic long-term report of 20 cases in humans. Int J Oral Maxillofac Implants $1999 ; 14: 835-840$.

- Qi MC, Zhou XQ, Hu J, Du ZJ, Yang JH, Liu M, Li XM. Oestrogen replacement therapy promotes bone healing around dental implants in osteoporotic rats. Int J Oral Maxillofac Surg. 2004;33:279-285.

- $\quad$ Rapuri PB, Gallagher JC, Nawaz Z. Caffeine decreases vitamin D receptor protein expression and 1,25(OH)2D3 stimulated alkaline phosphatase activity in human osteoblast cells. J Steroid Biochem Mol Biol 2007; 103: 368-71.

- $\quad$ Rasmusson L, Meredith N, Kahnberg KE, Sennerby L. Effects of barrier membranes on bone resorption and implant stability in onlay bone grafts. An experimental study. Clin Oral Implants Res 1999;4:267-77.

- Rocchietta I, Fontana F, Simion M. Clinical outcomes of vertical bone augmentation to enable dental implant placement: a systematic review. J Clin Periodontol. 2008;35:203-215

- $\quad$ Satue M, Petzold C, Cordoba A.UV photoactivation of 7 dehydrocholesterol on titanium implants enhances osteoblast differentiation and decreases Rankl gene expression. Acta Biomater. 2013;9:5759-5770.

- $\quad$ Sargolzaie N, Samizade S, Arab H, Ghanbari H, Khodadadifard L, Khajavi A. The evaluation of implant stability measured by resonance frequency analysis in different bone types. J Korean Assoc Oral Maxillofac Surg 2019;45:29-33

- Schopper C, Goriwoda W, Moser D. Long term results after guided bone regeneration with resorbable and microporous titanium membranes. Oral Maxillofac Surg Clin North Am , 2001; 13:449.

- Schropp L,Wenzel A,Kostopoulos L,Karring T. Bone healing and soft tissue contour changes following single-tooth extraction: a clinical and radiographic 12-month prospective study. Int J Periodontics Restorative Dent 2003; 23:313- 323 .
- Sennerby L, Meredith N. Implant stability measurements using resonance frequency analysis: biological and biomechanical aspects and clinical implications. Periodontol 2000 2008;47:51-66.

- Simion M, Scarano A, Gionso L, Piattelli A. Guided bone regeneration using resorbable and nonresorbable membranes: A comparative histologic study in humans. Int $\mathrm{J}$ Oral Maxillofac Implants 1996; 11:735.

- Simunek A, Kopecka D, Brazda T, Strnad I, Capek L, Slezak R. Development of implant stability during early healing of immediately loaded implants. Int J Oral Maxillofac Implants 2012;27:619- 27.

- St-Arnaud R. The direct role of vitamin D on bone homeostasis. Archives of Biochemistry and Biophysics 2008; 473: $225-230$

- Stoffels K, Overbergh L, Giulietti A. Immune regulation of 25 hydroxyvitamin- D3-1alpha-hydroxylase in human monocytes. J Bone Miner Res. 2006;21: 37-47.

- Susarla SM, Chuang SK, Dodson TB. Delayed versus immediate loading of implants: Survival analysis and risk factors for dental implant failure. J Oral Maxillofac Surg. 2008;66:251-5.

- Turkyilmaz I, Tözüm TF, Tumer C, Ozbek EN. Assessment of correlation between computerized tomography values of the bone, and maximum torque and resonance frequency values at dental implant placement. J Oral Rehabil 2006;33:881-8.

- Van der Meij EH, Blankestijn J, Berns RM, Bun RJ, Jovanovic A, Onland JM, Schoen J. The combined use of two endosteal implants and iliac crest onlay grafts in the severely atrophic mandible by a modified surgical approach. Int J Oral Maxillofac Surg 2005;34:152-7.

- van Leeuwen JP1, van Driel M, van den Bemd GJ, Pols HA. Vitamin D control of osteoblast function and bone extracellular matrix mineralization. Crit Rev Eukaryot Gene Expr. 2001; 11: 199-226.

- Van Steenberghe D, Johansson C, Quirynen M. Bone augmentation by means of a stiff occlusive titanium barrier. Clin Oral Implants Res 2003; 14:63.

- Verhoeven JW, Ruijter J, Cune MS, Terlou M, Zoon M. Onlay grafts in combination with endosseous implants in severe mandibular atrophy: one year results of a prospective, quantitative radiological study. Clin Oral Implants Res 2000;11:583-94. 
- Vermeeren JI, Wismeijer D, van Waas MA. One-step reconstruction of the severely resorbed mandible with onlay bone grafts and endosteal implants. A 5-year follow-up. Int J Oral Maxillofac Surg 1996;25:112-5.

- Von Arx T, Hardt N,Wallkamm B. The TIME technique: a new method for localized alveolar ridge augmentation prior to placement of dental implants. Int J Oral Maxillofac Implants. 1996;11: 387-394.

- Von Arx T, Wallkamm B, Hardt N. Localized ridge augmentation using a micro titanium mesh: A report on 27 implants followed from 1 to 3 years after functional loading. Clin Oral Implants Res , 1998; 9:123.

- Watzinger F, Luksch J, Millesi W. Guided bone regeneration with titanium membranes: A clinical study. Br J Oral Maxillofac Surg 2000;38:312.

- Weber HP, Crohin CC, Fiorellini JP. A 5-year prospective clinical and radiographic study of non-submerged dental implants. Clin Oral Implants Res 2000;11:144-53

- $\quad$ Xu L, Zhang W, Lv K, Yu W, Jiang X, Zhang F. Periimplant bone regeneration using rhPDGFBB, BMSCs, and betaTCP in a canine model. Clin Implant Dent Relat Res. 2015.

- Zablotsky M, Meffert R, Caudill R. Histological and clinical comparisons of guided tissue regeneration on dehisced hydroxylapatite-coated and titanium endosseous implant surfaces. A pilot study. Int J Oral Maxillofac Implants 1991 6:294.

- Zhou C, Li Y, Wang X. 1,25Dihydroxy vitamin D(3) improves titanium implant osseointegration in osteoporotic rats. Oral Surg Oral Med Oral Pathol Oral Radiol. 2012;114:S174-S178.

- Zitzmann NU, Naef R, Scharer P. Resorbable versus nonresorbable membranes in combination with BioOss for guided bone regeneration. Int J Oral Maxillofac Implants, 1997; 12:844. 